\title{
Control of Fusarium verticillioides using Palmarosa essential oil (Cymbopogon martinii)
}

Kevison Romulo da Silva Franca ${ }^{1 *}$, Alda Leaby dos Santos Xavier ${ }^{1}$, Flavia Mota de Figueredo Alves ${ }^{1}$, Tiago Silva Lima ${ }^{1}$, Ionaly Gomes de Araújoº , Lídia Pinheiro da Nóbrega ${ }^{1}$, Antônio Hugo Costa Nascimento ${ }^{2}$, Antônio Francisco de Mendonça Júnior ${ }^{3}$, Ana Paula Medeiros dos Santos Rodrigues ${ }^{4}$, Antônio Fernandes de Almeida ${ }^{5}$ and Tiago Augusto Lima Cardoso ${ }^{6}$

\author{
${ }^{1}$ Agroindustrial Systems, Federal University of Campina Grande, Pombal, PB, Brazil \\ ${ }^{2}$ Environmental Engineer, Federal University of Campina Grande, Pombal, PB, Brazil \\ ${ }^{3}$ Department of Agronomy, Rural Federal University of Pernambuco, Recife, PE, Brazil \\ ${ }^{4}$ Postgraduate in Agronomy/Plant Protection, Rural Federal University of Semiarid, \\ Mossoró, RN, Brazil \\ ${ }^{5}$ Departament of Agronomy, Federal University of Campina Grande, Pombal, PB, Brazil \\ ${ }^{6}$ Phytopathology Laboratory, Federal University of Campina Grande, Pombal, PB, Brazil
}

*Corresponding author

\section{A B S T R A C T}

\section{Keywords}

Alternative control, Mycelial growth, Plant diseases, Seeds pathology, Zea mays $\mathrm{L}$.

Article Info

Accepted:

07 April 2019

Available Online:

10 May 2019
This study aimed to evaluate the fungi toxic effect of palmarosa essential oil (Cymbopogon martinii) on mycelial growth of Fusarium verticillioides in vitro and treatment of corn seeds. For the in vitro experiment the essential oil was added to the culture medium and poured into Petri dishes, using seven different oil concentrations $(0.0125,0.025,0.05,0.1$ and $0.2 \%), 0.0 \%$ was the negative control, and we used Thiram as a positive control. Discs of culture medium with fungal mycelium were inoculated into the center of the plates and incubated for seven days at $27 \pm 2{ }^{\circ} \mathrm{C}$. Growth was evaluated and the percentage of mycelial growth inhibition and mycelial growth rate index were calculated. For corn seed experiment, seven different oil concentrations $(0.1,0.2,1.0,3.0,5.0$, and $6.0 \%)$ were used, and $0.0 \%$ was the negative control, and Thiram the positive control. The artificial inoculation was carried out in fungi colonies and the seed sanity test performed. The percentage of seeds infected by the fungus was evaluated after seven days. Under in vitro conditions, palmarosa oil reduced the mycelial growth of $F$. verticillioides at all concentrations tested. The highest dose, $0.2 \%$, totally inhibited fungus growth. In seed treatment, the oil significantly reduced the percentage of infected seeds above $3.0 \%$ of concentration.

\section{Introduction}

Corn (Zea mays L.) is the second most important crop of Brazilian agribusiness. It is estimated the production of 96 million tons in the harvest of 2018/2019, characterizing the country as the third largest producer and second in the export classification of this 
cereal (Conab, 2019). Almost all production is consumed internally (Alves, 2007), allocating around 70 to $80 \%$ to animal feed and feed industry: $51 \%$ are directed to the poultry sector, $33 \%$ to swine, $11 \%$ to livestock, and 5\% for food supplementation of other animals (Queiroz et al., 2012).

Due to the economic importance of maize and the adoption of technologies by producers, the demand for high-quality seeds has increased, causing companies to adopt quality standards that are more stringent than those established by the certification system (Fantazzini et al., 2016). Despite all the technology employed, maize is a crop susceptible to several diseases that reduce productivity and lead to significant economic losses.

In Brazil, fungi from the genus Fusarium cause the main diseases associated with maize, mainly the species Fusarium verticillioides and $F$. graminearum, which cause root rot, seedling death, stem rot, and stem rot, responsible for losses in infected crops (Munkvold, 2003). F. verticillioides has been found in corn seeds produced in the country, so infected seeds represent survival sites and important vehicle of dissemination of phytopathogen (Ribeiro et al., 2005; Nerbass et al., 2008).

The chemical treatment of seeds with fungicides is the main measure adopted (Goulart and MeloFilho, 2000). However, this conventional practice has caused serious environmental, economic and public health problems, since residues remain for a long time in the environment, contaminating the natural resources and crops produced, which reach consumers with noxious substances (Cruz and Farias, 2017).

The use of alternative products with similar effects to conventionally used chemical pesticides, but not harmful to the environment or to human health is a present need. Among the products widely tested, the essential oils extracted from aromatic plants have shown satisfactory antifungal effect in the in vitro control of phytopathogens (Sousa, Serra and Melo, 2012; França et al., 2018; Ugulino et al., 2018; Nóbrega et al., 2019), and seed treatment (Hillen et al., 2012), with low toxicity, rapid degradation by the environment, and safer to human health (Silva et al., 2018). The essential oils can be used in an integrated way to other management techniques contributing to the reduction of the use of synthetic chemical inputs (Machado, Silva and Oliveira, 2007).

The essential oil of palmarosa (Cymbopogon martinii) has an antifungal activity well documented in the literature, and its biological activity has been studied in the last years. The main constituents of palmarosa oil are geraniol $(82 \%)$, geranyl acetate $(9 \%)$, linalool (2\%), tran- $\beta$-ocimene (1\%), and geraniol is the main constituent associated with its antimicrobial activity (Scherer $e t$ al., 2009). The use of palmarosa oil present promising results in the control of phytopathogens, such as Fusarium solani (Nascimento, Vieira and Kronka, 2016), Phomopsis azadirachtae (Prasad et al., 2012) and Rhizoctonia solani (Hillen et al., 2012)

Taking in account the importance of seeds to the production system and the susceptibility to phytopathogens (Berger, Sinha and Roitsch, 2007), phytosanitary treatments with environmentally safe products are current market demand, avoiding negative influence by chemical fungicides (Hillen et al., 2012). Therefore, in this study, we aimed to evaluate the fungi toxic potential of palmarosa essential oil in the inhibition of the mycelial growth of Fusarium verticillioides as well as its efficiency in the maintenance of the sanitary quality of corn seeds. 


\section{Materials and Methods}

\section{Experiment location and materials}

The work was conducted at the Center of Science and Technology Agrifood (CCTA) of the Federal University of Campina Grande (UFCG), Campus of Pombal. The experiments were carried out in the Phytopathology laboratory, from January to March, 2019.

We used the strain 3434 of Fusarium verticillioides yielded by the collection of phytopathogenic fungi Prof. Maria Menezes of the Federal Rural University of Pernambuco, preserved until the assay in sterile distilled water by the Castellani method.

The essential oil of palmarosa (Cymbopogon martinii) was used, obtained by the steam distillation process, according to the techniques adopted by FERQUIMA Indústria e ComércioLimitada, Vargem Grande / São Paulo. Hybrid corn seeds AG 1051 were purchased at a commercial house in the city of Pombal, with a minimum purity of $98 \%$ and a minimum germination of $85 \%$.

\section{Experimental design}

\section{Effect of palmarosa essential oil (Cymbopogon martinii) on Fusarium verticillioidesin vitro}

The experiment had a completely randomized design consisting of seven treatments (5 oil concentrations, 1 negative control and 1 positive control) in five replicates each. The treatments consisted of autoclaved medium supplemented with pure palmarosa essential oil at different concentrations $(0.0125,0.025$, 0.05 and 0.1 and $0.2 \%$ ), the negative control $(0.0 \%)$, and the positive control consisting of commercial fungicide supplementation
Thiram at the manufacturer's recommended concentration $\left(1 \mathrm{~mL} \mathrm{~L}^{-1}\right)$.

The treatments were incorporated into the autoclaved flux-BDA (Potato Dextrose Agar) culture medium. After cooling, the medium was poured into $7.5 \mathrm{~cm}$ diameter Petri dishes under aseptic conditions. Disks of $1 \mathrm{~cm}$ diameter culture medium containing mycelia of the fungus were transferred to the center of each plate containing the treatments. The plates were then wrapped in plastic film and incubated in a B.O.D type oven (Biochemical Oxygen Demand) at a temperature of $27 \pm 2^{\circ}$ C.

Colony growth was measured daily until the colony took the entire surface of the culture medium from one of the plaques or in a maximum period of 7 days. Mycelial growth evaluation consisted of daily measurements of the diameter of the colonies obtained through the average of two perpendicular measurements, using a graduated ruler, resulting in the average daily growth for each repetition of each treatment.

The percentage of mycelial growth inhibition (PGI; Bastos, 1997) and mycelial growth rate index (IMGS; Oliveira, 1991) were calculated according to formulas (1) and (2):

$P G I=\frac{[\text { (negativecontrolgrowth }- \text { treatmenttgrowth })] \times 100}{\text { negativecontrolgrowth }}$
$I M G S=\sum \frac{\text { currentmyyclialgrowth-previousmycelialgrowth }}{\text { numberof daysof incubation }}$

Effect of palmarosa essential oil (Cymbopogon martinii) on Fusarium verticillioides in maize seeds

The experimental consisted of a completely randomized design with 8 treatments of sterilized distilled water solutions supplemented with palmarosa essential oil at the concentrations $0.1,0.2,1.0,3.0,5.0$ and 
$6.0 \%$, a negative control, $0.0 \%$, and a positive control supplemented with the commercial fungicide Thiram at the recommended dose (1 $\left.\mathrm{mL} \mathrm{L}^{-1}\right)$. The concentrations used were determined based on the in vitro test results. To allow the emulsion between oil and water we used Tween 80 (1 mL L $\left.{ }^{-1}\right)$ (Santos, 2018).

The seeds were disinfested in $2 \%$ sodium hypochlorite solution for five minutes, washed with sterile distilled water twice and dried at room temperature. Afterwards they were immersed for five minutes in the different solutions (treatments). After drying at room temperature, the artificial inoculation was performed.

The inoculation was done depositing the seeds on colonies of Fusarium verticillioides with 7 days of age. The seeds and the fungal colonies stayed for 32 hours in a B.O.D (Biochemical Oxygen Demand) type greenhouse at $27 \pm 2{ }^{\circ} \mathrm{C}$, with a 12-hour photoperiod (Ramos et al., 2014).

After the treatment and inoculation, the sanity test of seeds was performed by the filter paper method with freezing (Limonard, 1966). Six hundred seeds of the hybrid (100 per treatment) were used, distributed in Petri dishes of $14 \mathrm{~cm}$. Ten seeds were placed equidistantly on each plate, on a triple layer of filter paper previously moistened in sterile distilled water, and incubated initially for 24 hours at $27 \pm 2^{\circ} \mathrm{C}$ with 12 -hour photoperiod. After this period they were subjected to freezing $\left(-20^{\circ} \mathrm{C}\right)$ for 24 hours, and then returned to the incubator for another five days.

After incubation, the seeds were evaluated individually, using a stereoscopic microscope for the quantification of the seeds infected by Fusarium verticilioides (Sacc.) Nirenberg. The results were expressed as percentage of infected seeds.

\section{Statistics}

To verify the effect of oil concentration on fungal growth, we used quadratic plateau regressions model for in vitro experimental data and linear model for in vivo experiment data. Regressions were performed using $\mathrm{R}$ Core Team 3.5.1 software.

Due to the lack of variance in the results of some treatments, the data were analyzed by applying non-parametric tests. The difference between treatments was verified by applying the Mann-Whitney (Tukey non-parametric) multiple comparisons. Differences with a probability value below 5\% were significant. The analyses were performed using Past 3.12 (Hammer, Harper and Ryan, 2001).

\section{Results and Discussion}

\section{Effect of palmarosa essential oil on mycelial growth of Fusarium verticillioides in vitro}

All tested concentrations of palmarosa essential oil inhibited mycelial growth of Fusarium verticillioides. Inhibition percentages increased significantly with the concentrations tested until reaching the maximum value $(\mathrm{PGI}=100 \%)$ at the highest concentration $(0.2 \%)$ (Fig. 1A). The rate of mycelial growth decreased with increasing concentration of palmarosa oil. The minimum value occurred (IMGS $=0 \mathrm{~cm} \mathrm{day}^{-1}$ ) also in the highest concentration (0.2\%) (Fig. 1B).

According to the literature, the monoterpene Geraniol is the major constituent of palmarosa soil, in addition to other chemical components such as geranial, linalool, thymol, limonene, $\alpha$-felandren, ocimene, germacrene-D and isomentol that contribute to its potent antifungal activity (Scherer et al., 2009, Kalagatur et al., 2018). The mechanisms of action of essential oil include lipid 
peroxidation, inhibition of ergosterol biosynthesis and increase of reactive oxygen species (ROS), which cause permeability of cell membranes promoting loss of essential molecules and affecting vital processes that trigger the process of cell death by apoptosis (Kalagatur et al., 2018).

Nascimento, Vieira, and Kronka (2016) found similar inhibition results on Fusarium solani f. sp. glycines at concentrations ranging from 1,000 to $8,000 \mu \mathrm{L} \mathrm{L}^{-1}(0.1$ to $0.8 \%)$, under in vitro conditions. The oil also inhibited Sclerotiumrolfsii, showing maximum inhibition of mycelial growth in the concentrations 500, 1000 and $1500 \mathrm{ppm}$ (0.05, 0.1 and $0.15 \%$ ) (Guerra et al., 2015). And, Khan and Ahmad (2012) testing the control of Aspergillus fumigatus, obtained maximum inhibition of $98.36 \%$ in the highest concentration tested $(0.32 \%)$. Although it is a small variation, it suggests that palmarosa essential oil may exert different antimicrobial activity depending on the microorganism studied, which justifies the investigation of its minimum inhibitory concentration in other phytopathogenic species.

Essential oil from other plant species also significantly inhibited $F$. verticillioides. For example, basil oil (Ocimum basilicum L.) lead to total inhibition of fungal growth in the concentration of $5 \mu \mathrm{L} \quad \mathrm{mL}^{-1} \quad(0.5 \%)$ (Dambolena et al., 2010).

Using cinnamon oil (Cinnamomum spp.) at concentration of $60 \mu \mathrm{L} \mathrm{L}^{-1}(0.06 \%)$, Xing et al., (2014) found maximum mycelial growth, while Bomfim et al., (2015) using rosemary oil (Rosmarinus officinalis L.) obtained maximum inhibition of $79.3 \%$ and $600 \mu \mathrm{g}$ $\mathrm{mL}^{-1}(0.06 \%)$.

To understand the potential of palmarosa essential oil as a fungicide on $F$. verticilioides, we compared its fungitoxic effect with the effect of a commercial synthetic fungicide. We found a stronger inhibition effect of the essential oil concerning the fungicide in the highest concentration tested (Fig. 2), suggesting that under in vitro conditions the commercial synthetic fungicide can be replaced by the essential oil.

The microbial control promoted by the essential oils occurs through the synergism or antagonism between several of its constituents (Bagamboula; Uyttendaele, Debevere, 2004; Russo et al., 2013) that act through different mechanisms of action in several targets at the same time (Abdel-Kader, El-Mougy and Lashin, 2012; Hoyos et al., 2012). These characteristics confer advantages over the synthetic fungicide since they decrease the phytopathogen resistance (Feng; Zheng, 2007).

Effect of palmarosa essential oil on mycelial growth of Fusarium verticillioides in maize seeds

Using maize seeds, the essential oil of palmarosa exerted significant inhibitory effect on $F$. verticillioides from the concentration of $3 \%$. Levels higher than $3 \%$ reduced the seed infection up to $21 \%$ at the highest concentration (6\%) (Fig. 3). The model regression estimated a total reduction of infected seeds at a concentration of $7.12 \%$.

The present study results showed that biologically active compounds present in palmarosa oil promote a significant antifungal effect on the mycelial growth of $F$. verticillioides under in vitro conditions and in the treatment of seeds. When using the oil at the concentration of $0.2 \%$ we obtained total inhibition of mycelial growth under in vitro conditions. However, in seed treatment, a higher concentration is required to obtain significant inhibition of the fungus $(<21 \%$ of infected seeds). 
Fig.1A Effect of differentsconcentrations of palmarosa essential oil on the mycelial growth of Fusarium verticillioides. 1B. Effect of differentsconcentrations of palmarosa essential oil on the mycelial growth speed of Fusarium verticillioides

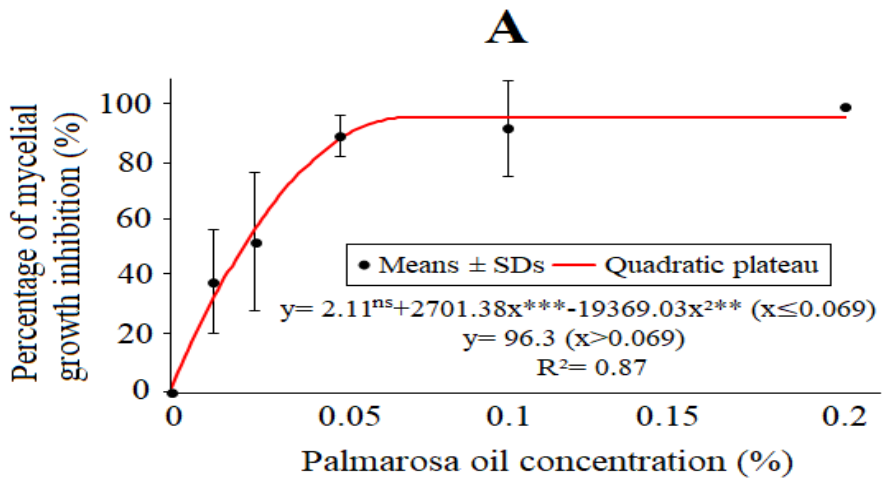

\section{B}

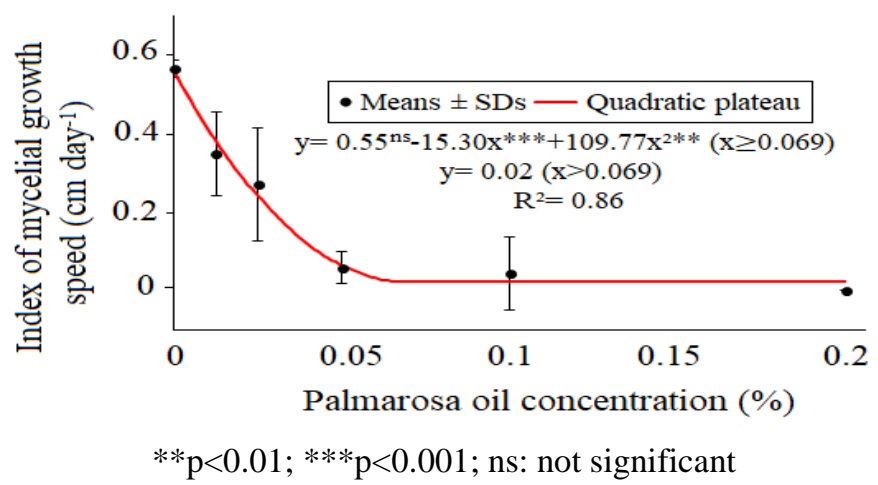

Fig.2 Inhibition of mycelial growth of Fusarium verticillioides in the different concentrations of palmarosa essential oil and the control treatments

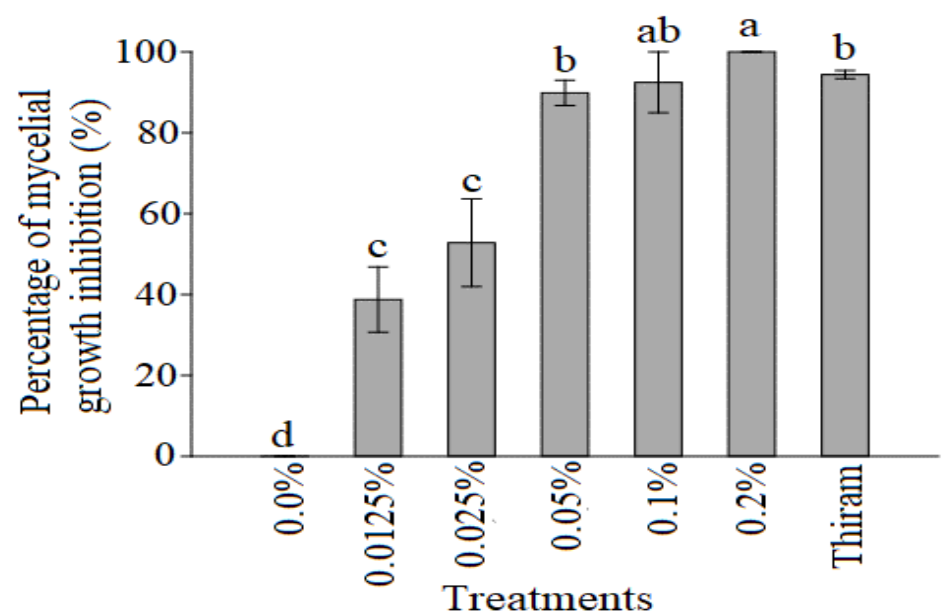

Superscript concentrations with the same letter were not significantly different from each other by the MannWhitney test $(\mathrm{p}>0.05)$ 
Fig.3 Effect of differentsconcentrations of palmarosa essential oil on the incidence of infected seeds by Fusarium verticillioides

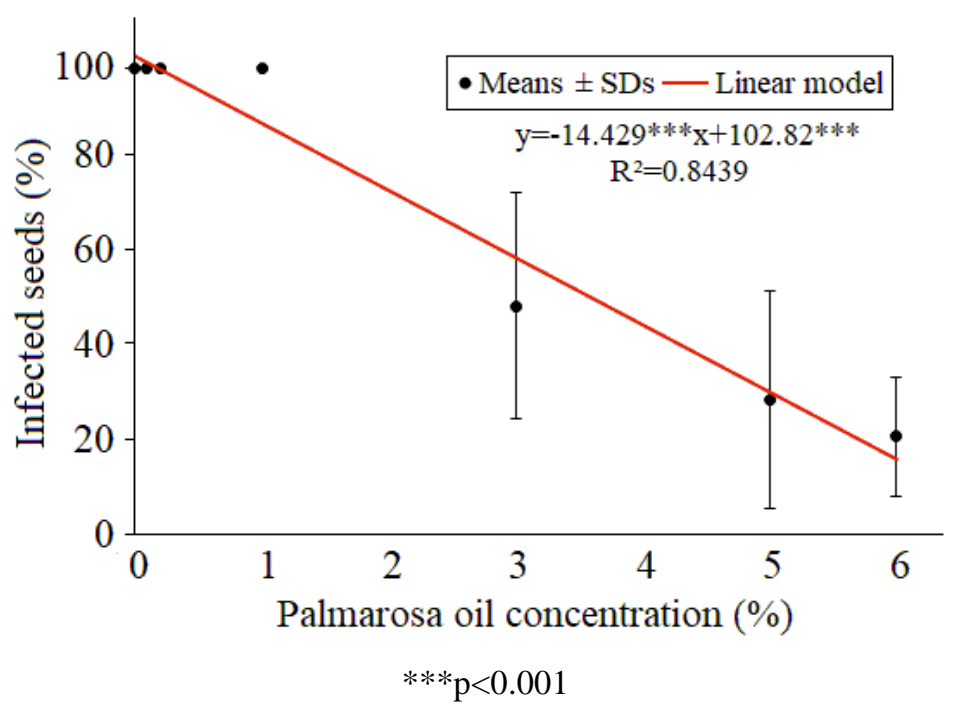

Fig.4 Percentage of infected seed byFusarium verticillioides after the treatment with the different concentrations of palmarosa essential oil and the control treatments

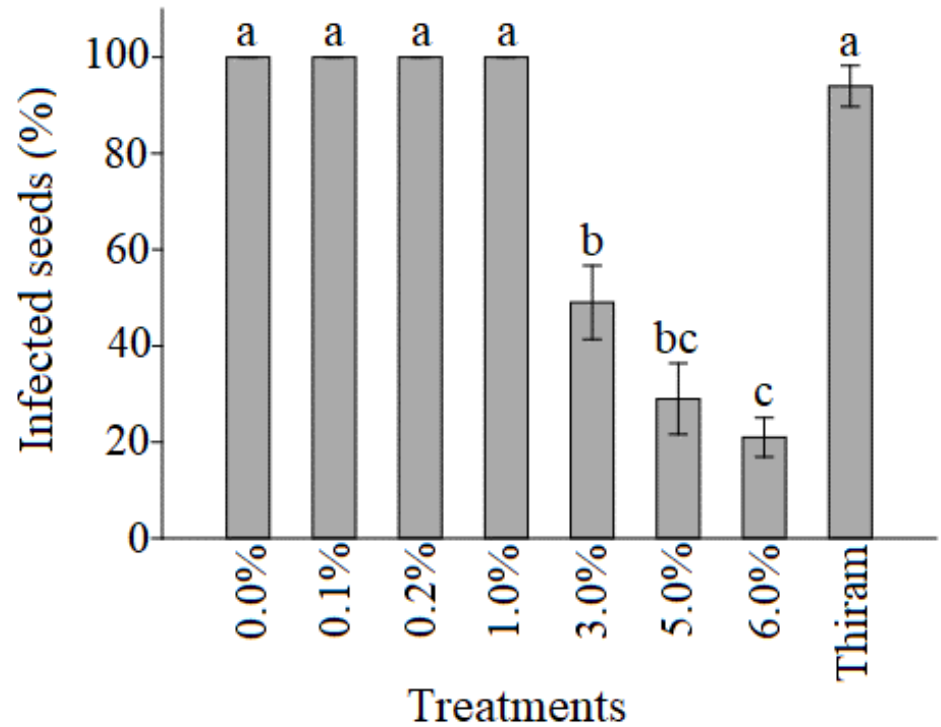

Superscript concentrations with the same letter were not significantly different from each other by the MannWhitney test $(\mathrm{p}>0.05)$

Fandohan et al.(2004) found significative results of the effect of lemon grass essential oil (Cymbopogon citratus) on the in vitro and corn seeds control of $F$. verticillioides. Under in vitro conditions, lemon grass oil totally inhibited mycelial growth from the concentration of $1.3 \mu \mathrm{L} \mathrm{mL}^{-1}(0.13 \%)$. However, in the seed treatment it was also 
necessary to increase the concentration so that there was a reduction in the percentage of infected seeds.

The essential oil of palmarosa was more efficient reducing seed infection than the fungicide Thiram above $3 \%$ of concentration (Figure 4). Despite needing a higher concentration of oil to have a significant reduction in infected seeds concerning the Thiram, the use of a natural and healthy product might be a better alternative to control the fungus. However, minimum recommended concentrations should be considered to avoid toxicity in humans and the environment.

According to Isman (2000), oils with the best antifungal activities are toxic at high concentrations. To test their constituents alone is suggested, since the action of different compounds present in the oil at high dosages may be responsible for their toxicity. Palmarosa oil, as well, is safe for human health when used in low concentrations (Sinha et al., 2014).

There is a growing interest in alternative products to chemical pesticides because of their high toxicity to humans and the environment. Therefore, there is a demand motivated by different priorities, such as health benefits, food security and environmental sustainability (Abdel-Kader, El-Mougy and Lashin, 2012).

Our results can be used for the formulation of natural defenses based on palmarosa essential oil, to implementation in agroecological crops, promoting the reduction of environmental impacts caused by the exclusive use of chemical pesticides. However, it is important to establish safe concentrations, respecting the oil toxicity limit.
Palmarosa essential oil (Cymbopogon martinii) totally inhibited the mycelial growth of Fusarium verticillioides under in vitro conditions from $0.2 \%$ concentration. In the treatment of hybrid corn seeds AG 1051, significantly reduced the percentage of infected seeds from $3 \%$ of oil concentration. The essential oil showed a higher effect than the obtained by the commercial fungicide Thiram.

\section{References}

Abdel-Kader, M.M., El-Mougy, N.S., and Lashin, S.M. 2011. Essential oils and Trichoderma harzianum as an integrated control measure against faba bean root rot pathogens. Journal of Plant Protection Research. 51(3):306-311.

Alves, G.C., 2007. Efeito da Inoculação de Bactérias dos Gêneros Herbaspirillum e Burkholderia na Cultura do Milho. Rio de Janeiro: UFRRJ, 2007. 53 p. Dissertação (Mestrado) - Curso de Pós-Graduação em Agronomia, Área de Concentração em Ciência do Solo, Universidade Federal Rural do Rio de Janeiro, Seropédica.

Bagamboula, C.F., Uyttendaele, M., and Debevere, J. 2004. Inhibitory effect of thyme and basil essential oils, carvacrol, thymol, estragol, linalool and p-cymene towards Shigella sonnei and S. flexneri. Food Microbiology. 21:33-42.

Bastos, C.N., 1997. Efeito do óleo de Piper aduncumsobre Crinipelis perniciosae outros fungos fitopatogênicos. Fitopatologia Brasileira. 22(3):441443.

Berger, S., Sinha, A.K., and Roitsch, T. 2007. Plant physiology meets phytopathology: plant primary metabolism and plant-pathogen interactions. Journal of Experimental 
Botany. 58(15/16): 4019-4026.

Bomfim, N.S., et al., 2015. Antifungal activity and inhibition of fumonisin production by Rosmarinus officinalis L. essential oil in Fusarium verticillioides (Sacc.) Nirenberg. FoodChemistry. 166:330-336.

Castellani A., 1967. Maintenance and cultivation of common pathogenic fungi of man in sterile distilled water. Further Researches. Journal of Tropical Medicine and Hygiene, 70: 181-184.

Companhia Nacional de Abastecimento. 2018. Perspectivas para a agropecuária. Brasília. 6: 1-112, 2018. Disponível em: www.conab. gov.br Acesso em: 09/03/2019.

Cruz, R.H.R., and Farias A. L. A. (2017). Impactos Socioambientais de Produção de Palma de dendê na Amazônia Paraense: Uso de Agrotóxicos. Revista GeoAmazônia. 5(10): 86-109.

Dambolena. J.S., et al., 2010. Essential oils composition of Ocimum basilicum L. And Ocimum gratissimum L. From Kenya and their inhibitory effects on growth and fumonisin production by Fusarium verticillioides. Innovative Food Science and Emerging Technologies. 11:410-414.

Fandohan, P., et al., 2004. Effect of essential oils on the growth of Fusarium verticillioides and Fumonisin contamination in corn. Journal of Agricultural and Food Chemistry. 52(22): 6824-6829.

Fantazzini, T.B., et al., 2016. Fusarium verticilioides inoculum potential and its relation with the physiological stored corn seeds quality. Bioscience Journal. 32(5): 1254-1262.

Feng, W., and Zheng, X. (2007). Essential oils to control Alternaria alternatain vitro and in vivo. Food Control.
18:1126-1130.

França, K.R.S. et al., 2018. In vitro effect of essential oil of peppermint (Mentha $x$ piperita L.) on the mycelial growth of Alternaria alternata. Journal of Experimental International. 26(5):1-7.

Agriculture

Goulart, A.C.P., and Melo Filho, G. A. Quanto custa tratar as sementes de soja, milho e algodão com fungicidas? Dourados: Embrapa Agropecuária Oeste, 2000. 23 p. (Documentos, 11).

Guerra, Y.L., et al., 2015. Control of Sclerotium rolfsii in peanut by using Cymbopogon martinii essential oil. African Journal of Microbiology Research. 9(7):1684-1961.

Hammer, O., Harper, D.A.T., and Ryan, P.D. 2001. Past: Paleontological statistics software package for education and data analysis. Paleontologia Electronica. 4(1): 9.

Hillen, T., et al., 2012. Atividade antimicrobiana de óleos essenciais no controle de alguns fitopatógenos fúngicosin vitro e no tratamento de sementes. Revista Brasileira de Plantas Medicinais. 14(3): 439-445.

Hoyos, J.M.A., et al., 2012. Antifungal activity and ultrastructural alterations in Pseudocercospora griseola treated with essential oils. Ciência $e$ Agrotecnologia. 36(3): 270-284.

Isman, M.B., 2000. Plant essential oils for pest and disease management. Crop Protection. 19: 603-608.

Kalagatur, N.K., et al., 2018. Antifungal activity of chitosan nanoparticles encapsulated with Cymbopogon martinii essential oil on plant pathogenic fungi Fusarium graminearum. Frontiers in Pharmacology. 9: 1-13.

Khan, M.S.A., and Ahmad, I. 2019. In vitro antifungal, anti-elastase and antikeratinase activity of essential oils of 
Cinnamo mum-, Syzygium- and Cymbopogon-species against Aspergillus fumigatus and Trichophyton rubrum. Phytomedicine. 19:48-55.

Limonard, T., 1966. A modified blotter test for seed health. Netherland Journal of Plant Pathology. 72(2):319-321.

Machado, L.A., Silva, V.B., and Oliveira, M.M. 2007. Uso de extratos vegetais no controle de pragas em horticultura. Biológico. 69(2):103-106.

Munkvold, G.P., 2003. Epidemiology of Fusarium diseases and their mycotoxins in maize ears. European Journal of PlantPathology. 109:705713.

Nascimento, D.M., Vieira, G. H. C., andKronka, A. Z. 2016. Inibição do crescimento micelial de Fusarium solanif. sp. glycines com o uso de óleos essenciais. Revista de Agricultura Neotropical. 3(4):65-68.

Nerbass, F.R., et al., 2008. Sanidade de sementes de milho comercializadas na safra agrícola de 2006/07 em Santa Catarina e no Rio Grande do Sul. Revista de Ciências Agroveterinárias. 7:30-36.

Nóbrega, L.P., et al., 2019. In vitro fungi toxic potential of copaiba and eucalyptus essential oils on phytopathogens. Journal of Experimental Agriculture International. 29(3):1-10.

Oliveira, J.A., 1991. Efeito do tratamento fungicida em sementes no controle de tombamento de plântulas de pepino (Cucumis sativas L.) e pimentão (Capsicumannum L.). 1991. $111 \mathrm{f}$. Dissertação (Mestrado em Fitossanidade) - Escola Superior de Agricultura de Lavras, Lavras.

Prasad, M.N.N., et al., 2011.In vitro efficacy of plant essential oils against Phomopsis azadirachtae the causative agent of die-back disease of neem. Archives of Phytopathology and Plant Protection. 44(5): 412-418.

Queiroz, V.A.V., et al., 2012. Occurrence of fumonisins and zearalenone in maize stored in family farm in Minas Gerais, Brazil. FoodControl. 28(1): 83-86.

$\mathrm{R}$ Core Team. A language and environment for statistical computing. $R$ Foundation for Statistical Computing, Vienna, Austria; 2018. Disponible in: https://www.R-project.org/.

Ramos, D.P., et al., 2014. Infecção por Fusarium graminearum e Fusarium verticillioides em sementes de milho. Pesquisa Agropecuária Tropical. 44(1):24-31.

Ribeiro, N.A., et al., 2005. Incidência de podridões do colmo, grãos ardidos e produtividade de grãos de genótipos de milho em diferentes sistemas de manejo. Ciência Rural, 35:1003-1009.

Russo, M., et al., 2013. Essential oil chemical composition and antifungal effects on Sclerotium cepivorum of Thymus capitatus wild populations from Calabria, Southern Italy. Revista Brasileira de Farmacognosia. 23(2): 239-248.

Santos, P.L., 2018. Manejo de Macrophomina phaseolina (Tassi) Goid. em sementes de feijoeiro (Phaseolus vulgaris L.) com óleos essenciais e antagonistas. 2018. 76fls. Tese (Doutorado em Agronomia) - Universidade Estadual Paulista, Botucatu-SP.

Scherer, R., et al., 2009. Composição e atividades antioxidante e antimicrobiana dos óleos essenciais de cravo-da-índia, citronela e palmarosa. Revista brasileira de plantas medicinais. 11(4):442-449.

Silva, B.V.S., et al., 2018. Efeito dos óleos essenciais sobre o crescimento micelial in vitro de Colletotrichum spp. Cadernos de Agroecologia. 
13(2):1-9.

Sinha, S., et al., 2014. Evaluation of toxicity of essentialoils palmarosa, citronella, lemongrassand vetiver in human lymphocytes. Food and Chemical Toxicology. 68, 71-77.

Sousa, R.M.S., Serra, I.M.R.S., and Melo, T. A. 2012. Efeito de óleos essenciais como alternativa no controle de Colletotrichum gloeosporioides, em pimenta. Summa Phytopathologica.
38(1): 42-47.

Ugulino, A.L.N., et al., 2018. Inhibition effect of vegetable oils on the mycelial growth of Macrophomina phaseolina (Tassi.). Goid. Journal of Agricultural Science. 10(6): 49-56.

Xing, F., et al., 2014. Growth inhibition and morphological alterations of Fusarium verticillioides by cinnamon oil and cinnamaldehyde. Food Control. 46: 343-350.

\section{How to cite this article:}

Kevison Romulo da Silva França, Alda Leaby dos Santos Xavier, Flavia Mota de Figueredo Alves,Tiago Silva Lima, Ionaly Gomes de Araújo, Lídia Pinheiro da Nóbrega, Antônio Hugo Costa Nascimento, Antônio Francisco de Mendonça Júnior, Ana Paula Medeiros dos Santos Rodrigues, Antônio Fernandes de Almeida and Tiago Augusto Lima Cardoso. 2019. Control of Fusarium verticillioides using Palmarosa essential oil (Cymbopogon martinii). Int.J.Curr.Microbiol.App.Sci. 8(05): 484-494. doi: https://doi.org/10.20546/ijcmas.2019.805.057 